\title{
Customer Centricity \& Competitive Intelligence Performance in the Insurance Industry in Western Kenya, East Africa
}

\author{
Angeline Atieno Oyomo \\ Moi University, School of Business \& Economics, Department of Human Resource \\ Studies, P. O. Box 3900-30100, Eldoret, Kenya
}

\begin{abstract}
Globally, inability to analyze information, to see past customer life cycle disruptions and dispassionately interpret events to anticipate competition threatens performance in the insurance industry. Organizations fail to respond and offer solutions desired by their customers, instead sticking to their traditional products not highly of customer choice. It was against this gap that this paper discussed Customer Centricity and its influence on competitive intelligence in Insurance Firms in Kenya. The objectives of this study were to determine effects of Customer Centricity on Competitive Intelligence of insurance firms in Kenya; to investigate whether Customer Life Cycle practices employed by insurance firms have effects on Competitive Intelligence; to assess whether the Customer Value practices affect Competitive Intelligence of insurance firms and establish the effects of Customer Experience on Competitive Intelligence of insurance firms in Eldoret Town in Kenya, East Africa. A mixed method design was used to study 250 selected from 600 employees of insurance firms in Eldoret. A semistructured questionnaire and an interview guide were used to collect data. Data were analyzed using selected descriptive and inferential statistics The results of applying Spearman and Friedman tests showed that customer centricity and its dimensions significantly affected competitive intelligence, with customer life as the most important, indicated by the Entropy technique. Customer experience emerged top when the Binomial test was applied. A recommendation is made that Managers in the insurance industry embrace all dimensions of customer centricity, especially the dimension of customer life cycles, in order to improve their competitive intelligence.

Keywords: Customer Centricity, Competitive Intelligence, Customer Life Cycle, Customer Value, Customer Experience
\end{abstract}

DOI: $10.7176 / \mathrm{EJBM} / 11-10-07$

Publication date: April $30^{\text {th }} 2019$

\section{Background of the Study 1}

Many insurance organisations are struggling with collection and analysis of information, past customer life cycle disruptions and dispassionate interpretation of events required for competitive intelligence in the insurance industry (Kwach, 2018). They lack insight of customer life cycle place dynamics and have challenges in using published and non-published sources. The practices applied are inadequate to provide desired growth and profitability. These companies cannot define, gather, analyze, and distribute intelligence information on customer experience centricity, customers, competitors, and any aspect of the environment needed to support executives and managers making strategic decisions for an organization. They continue to face high level exposure to risks, delivery of non-value added services and inability to improve their commercial performance.

Business environment has become highly competitive, turbulent and are constantly changing globally. Knowing the tricks of survival is the core value of performance since great customer experience centricity or services are not enough anymore. The trends are indications of a move from simple to complex, from stable to dynamic, and from friendly to hostile (Comai and Joaquin, 2007). In response to changing customer life cycle conditions, organizations that have maintained their traditional approaches have become vulnerable and are unable to perform in their competitive intelligence. In fact most managers lack information about impacts of customer needs that would influence on competitive intelligence performance.

Yet most of insurance companies, especially in developing countries like Kenya, are lacking growth drivers to move them from traditional customer experience centricity, services and approaches to what customers' desire in the changing business environment (Hair, J.F., Black, W.C., Babin, B.J., Anderson, R.E., and Tatham, R.L., 2010). These players have not been able to tap from their experience and become customer life cycle movers. Their customer experience centricity look the same and incremental improvements don't differentiate on a sustainable basis (Baars, H., and Kemper, H.G., 2008). Apart from that, insurance companies rarely add value to their services, hence the industry remain undifferentiated in their customer experience centricity and services offering (Hannula, M., and Pirttimaki, V., 2003). Companies with greater reliance on the service part of their business reportedly achieve better return on sales and improve their value (Hannula, M., and Pirttimaki, V., 2003). However, most of organisations do not adequately use the information obtained from the business environment to improve on their performance. Yet using feedback is one way that organizations can rebrand, innovate and creatively become customer life cycle leaders.

This is a major concern to the insurance sector, where risk evaluation, consumer behavior, customer 
experience centricity launches, and management all play strategic roles in success. In recent years these activities have become even more important as profit margins deteriorate and holding on to current customer life cycle share remains vital to the success of the firm (Gainor, 2014). The players in this industry hardly have driving data that provide a full picture of how the demand for insurance customer experience centricity and services is evolving. It means that the ability to understand competitor dynamics and undertake due diligence by providing in-depth data and analysis for insurers, intermediaries, reinsurers and insured is not possible (Kipkorir, 2001). In such a highly competitive industry, insurance companies need better insights to be able to gain a more holistic view of enterprise performance. In order to increase efficiency and boost profitability it is critical to make the optimal decisions and, in order to do this, they need the right competitive approaches (Adidam, Banerjee, and Shukla, 2012; Blenkhorn, and Fleisher, 2007; Bose, 2008; Clark, 2010; Dahl, 2010).

Further, most players in this sector are not able to solve complex issues, react quickly to customer life cycle trends and drive efficiencies. In an industry that is so incredibly unpredictable, the ability to predict changes in the customer life cycle can be a driving force to success. However, many operators are performing poorly as they keep providing traditional customer experience centricity and services without competitive value addition (Korany, 2007).

At the same time, inability to make decisions that alert management to early warning of both threats and opportunities is also faced. These insurance companies cannot discover that their current customer life cycles are exhausted and urgently need to discover new customer life cycles. This has always acted against their desire to beat their competitors, foresee competitor's actions, determine which companies to acquire, learn about new customer experience centricity and technologies that will affect the industry, and forecast political or legislative changes that will affect the company (Li, S.T., Shue, L.Y., and Lee, S., 2008). They suffer most since they are not able to establish best views of the customer life cycle and the competition. The insurance sector players in Kenya compete for a limited customer life cycle characterized by low penetration. Kenyans' uptake of insurance cover, both at corporate and personal level, remains predominantly in the motor, fire, industrial and personal accident (mainly group medical cover) classes.

This illustrates a poor grip on the business environment trends that can be interpreted to create more business opportunities. This has always resulted in the poor performance, closure of many organisations that cannot match to the set operational standards by insurance regulators. Moreover, due to demographic shifts, evolving aspirations and accelerating globalization, competitive focus is critical (Marceau, S. and Sawka, K., 2001). Yet the operators in this sector seem to lack capabilities needed. The ability to develop strategic approaches capable of anticipating and responding to evolving business needs and workforce expectations is essential if they need to competitively survive. But currently, many organisations are not able to identify and realize opportunities to differentiate benefits, career development prospects and other key aspects of their employment brand in home and emerging customer life cycles.

Organizations need to expand their view of the customer, other areas of value creation need to be evaluated, and companies are looking more closely at customer experience and creating emotional connections but are unable to identify early warnings of threats and blind spots in business, support strategic decision making. Hence are unable to build on these areas to create business opportunities. Such organizations lack the ability to sense, adapt and differentiate according to customer life cycle change which is increasingly important in competition. While their capacity to understand, predict and respond to customer, customer life cycle and competitor dynamics, demands and disruptions are essential tools of intelligence performance, many organisations are still not able to transcend individual departments and functions (McGonagle, J.J., and Vella, C.M. (2004).

In recent years, there has been a huge amount of investment aimed at improving insurance business intelligence \& analytics. Yet research from Gartner suggests that many insurance companies are still struggling to see the bigger picture as a result of underlying issues with their approach to data (Gainor, and Bouthillier, 2014; Garcia-Alsina, Ortoll, and Cobarsí-Morales, 2013; Leslau, 2010; Matthews, 2011). When we talk about business intelligence, we often focus on customer experience centricity-centric businesses (Mutua, 2010). These are companies with real, tangible goods and they often provide the best use case examples for the successful implementation of business intelligence solutions. With a physical customer experience centricity, it is easy to see how analytics can be used at every stage of the business from customer experience centricity on to supply chain to sales.

\subsection{Statement of the Problem 2}

Although customer centricity can be a tool that can be used for designing the experience, inadequate or lack of its practical application by most organisations makes it difficult to determine whether it is a tool that can be useful in improving on competitive intelligence performance (Ngugi J. K., Gakure R.W. and Mugo H., 2012).

The design of competitive intelligence, as a process that monitors all elements of the external environment of an organization is still recent. The increased use of the concept of competitive intelligence has been a function of globalizing the economy. Thus, countries have been using competitive intelligence on a global scale, as a 
guarantee of a place on the world scene. Japan, for example, has been using it since the Second World War and as a result was able to increase its customer life cycle advantage in the 1980s, forcing the countries of the West, particularly the United States, to react (Gilad, 1994).

Moreover, there are no such studies done in Uasin Gishu County of Kenya and the other parts of the country on customer centricity. Mutua (2010) did a research on competitive intelligence practices by Essar Telcom (YU) (K) Ltd. Muiva, (2001) conducted a survey on the use of competitive intelligence systems in the Kenyan Pharmaceutical Industry while Kipkorir, (2001) researched on competitive intelligence practices by FM radio stations operating in Kenya. These studies were however done on different institutions other than insurance firms in Kenya. This is despite the fact that the insurance industry in Kenya is facing many challenges posed by the competitive and complex modern environment in general. Despite the adoption of this customer centricity there is no study that has been done on the Kenyan insurance industry to date. This study therefore sought to fill the existing knowledge gap by carrying out an investigation of customer centricity practices for greater competitive intelligence in the insurance industry in Kenya.

\subsubsection{Significance of the Study 3}

The study is important to managers in the insurance sector and to larger extent managers of other industries. It would provide information useful in understanding the importance of customer centricity and how different firms can achieve competitive edge. The study also helps other managers know the methods used in gathering and applying customer centricity, which help them improve their management styles. The study acts as a source of reference material for future researchers on other related topics; it would also help other academicians who undertake the same topic in their studies. The study highlights other important relationships that require further research; this may be in the areas of relationships between customer centricity and competitive intelligence.

\subsubsection{Justification and Rationale of the Study 4}

Furthermore, in mature insurance industry slow growth and consolidation is a threat to growth and profitability. Price competition is accelerating as customers turn to insurers who offer the best deal on many types of insurance. In addition, while the insurance business and the needs of policy holders and distributors are rapidly changing, many insurance companies can't keep up. Their businesses are also undifferentiated and are also unable to reach customers likely to respond to new sales opportunities or make the most of their valued staff. Insurers that define and implement solutions to these challenges are those that will successfully compete and thrive into the future. These insurers are not able to influence persistency and retention support resulting in their inability to meet customer expectations in terms of service quality, rewarding loyalty, communication and customer experience centricity transparency.

\subsubsection{Literature Review 5}

Accelerated global competitiveness, reduced customer experience centricity life cycles, rapid technological advancements, and dynamic customer requirements have drastically altered the nature of industrial competition. Price (cost) is no longer the sole criteria for creating a sustainable competitive advantage (Hill, 1995). Firms must develop and deploy competitive intelligence driven by customer life cycle requirements. Many firms have adopted customer experience centricity, process, and service quality improvement as a key strategic initiative for achieving excellent performance levels (Adam, 1992) Firms must develop and deploy competitive intelligence driven by customer life cycle requirements due to global competition.

The Society of Competitive Intelligence Professionals (SCIP, 2008) are for the view that Competitive Intelligence is a systematic and ethical process for gathering, analyzing and managing external information that can affect the company's plans, decisions and operations. According to Bengtsson \& Kock (2000) the three types of competitive relationships include competition-dominated, cooperation-dominated, and equal relationships. Owing to the fact that specific developments in the business environment need to be closely monitored, it is imperative that senior corporate intelligence professionals think in terms of integrating competitive intelligence work with marketing intelligence work.

Many firms have adopted customer experience centricity, process, and service quality improvement as a key strategic initiative for achieving excellent performance levels (Adam, 1992). However, sustainable excellent performance will not occur if there is a misalignment between a firm's competitive strategies and actual customer life cycle requirements. In addition, globalization has caused competition to be a constant concern of organizations, by increasing the need for continuous evaluation of the competitive environment and the information coming out of it (McKenzie, van Winkelen, and Grewal, 2011; Sharma, and Dijaw, 2011; Yap, and Rashid, 2011). The insurance sector is currently in a state of some uncertainty and companies are increasingly conscious of the need to maintain a competitive edge over their commercial rivals while at the same time getting maximum benefits from in-house resources.

This statistics fall in place owing to the stiff competition in the industry and reluctance of the Kenya population to subscribe for insurance. This reluctance could owe to either ignorance or lack of incentives and diverse services to accommodate their diverse needs and finances. Even though the insurance industry is a major contributor in the growth of an economy, it happens to be a marginal player in the lives of most Kenyans. This is 
the reverse of the situation in most rapidly developing or developed countries. It is of fundamental importance for the survival of an insurance company to obtain a competitive edge (Cobarsí-Morales, 2013). The company must anticipate change, recognize opportunities, and monitor continuously the information flow about other businesses and activities in the same field.

Most researchers have studied the aspect of competitive intelligence in various sectors, for example, Muiva, (2001) conducted a survey of the use of competitive intelligence systems in the Kenyan pharmaceutical industry while Kipkorir, (2001) studied competitive intelligence practices by FM radio stations operating in Kenya. To the best of the researchers' knowledge, no study has ever investigated competitive intelligence activities undertaken in the insurance industry. Towards this end, it is therefore necessary to carry out a study on how different insurance companies apply competitive intelligence to maintain a competitive edge. This study tries to investigate competitive intelligence practices in insurance industry in Kenya.

The concept of centricity has a rich history of over 2,000 years (Juhari and Stephens, 2006). The centricity concept as part of customer life cycling strategy has long been proposed as an effort to increase the firm's competitiveness and its strategic planning process (Guyton, 1962; Montgomery and Urban, 1970; Pearce, 1976; Montgomery and Weinberg, 1979; Porter, 1980). Since that time, this proposition has grown to become an emerging business construct with delineated job functions directly responsible for intelligence collection, analysis, and dissemination (Kahaner, 1996). The concept of CC has a rich heritage (Juhari and Stephens, 2006) and can be traced back over 5,000 years of Chinese history (Qingjiu and Prescott, 2000). These and other authors point to examples in various religions and historical contexts which address intelligence concepts. Many CC literatures refer to the work of Sun Tzu who, some 2,400 years ago, wrote The Art of War, a seminal text which provides a detailed description of how to develop intelligence for military applications (Sun, 1988).

Further, many centricity researchers cite Frederick the Great (1740-1786), who was once quoted as saying "It is pardonable to be defeated, but never to be surprised" (Fuld, 1995). Wright et al. (2004) remind us that competitive intelligence is not a new concept. This is evidenced by Nathan Rothschild's timely intelligence to make a fortune on the London Stock Exchange following the Battle of Waterloo in 1815 (McKenzie, van Winkelen, and Grewal, 2011). Among Rothschild's intelligence network was an agent who watched Napoleon's defeat at Waterloo and subsequently sent carrier pigeons to Rothschild, who the following morning sold large volumes of shares.

Observers wrongly concluded that the French had won the battle, and shares slumped. Rothschild then bought back and awaited the news, which arrived conventionally, that Wellington had won. The customer life cycle correction helped Rothschild to his fortune (Ferguson, 1998). Historical records point towards commercial collection activities happening even earlier. The Byzantine emperor Justinian I (483-565) in the sixth century used monks to steal silk worms from the Chinese in an attempt to understand how to make silk (Fraumann, 1997). Although this is more an example of what would now be termed "industrial espionage" than CC, it does demonstrate how long there have been efforts to scan the environment for information that will provide organizations or countries with a competitive intelligence.

Wickham learned about the Chinese customer experience centricity on of tea over ten years and then, thanks to various inventions such as tea boxes and chests, he was able to successfully start a tea industry in Britain (Breed, 1999).As can be seen from the examples given above, whilst today it is reported that 87 per cent of all large companies, regardless of locations, have an intelligence capability (Global Intelligence Alliance, 2005), it can be seen that the commercial application of competitive intelligence, has been around for at least 5,000 years if not longer. The analysis of the literature allows to state that the term of "Customer Centricity" dates back to many years ago. Sawka (1996) defines CC as a knowledge and foreknowledge about the external operating environment. The author considers $\mathrm{CC}$ as a prelude to informed decision-making. He argues that intelligence can be viewed as any actionable information about a customer, customer life cycle situation, regulator and competitor. The Society of Customer Centricity Professionals, an official US-based intelligence organization, defines Customer Centricity as "timely and fact-based data on which management may rely on decision-making and strategy development. It is carried out through industry analysis, which means understanding the players in a industry; competitive analysis, which means understanding the strengths and weaknesses of competitors; and benchmarking i.e. the analysis of individual business process of competitors" (Calof, 1997).

\subsubsection{Conceptual Framework 7}

Figure 1 illustrates the influence of Customer Centricity on competitive intelligence. In the framework, customer centricity and its dimensions include customer life cycle; customer value and customer experience are independent variables and competitive intelligence dimensions include market dominance, information discovery and predicting the future as dependent variables. 
Figure 1: Conceptual Framework of the Research

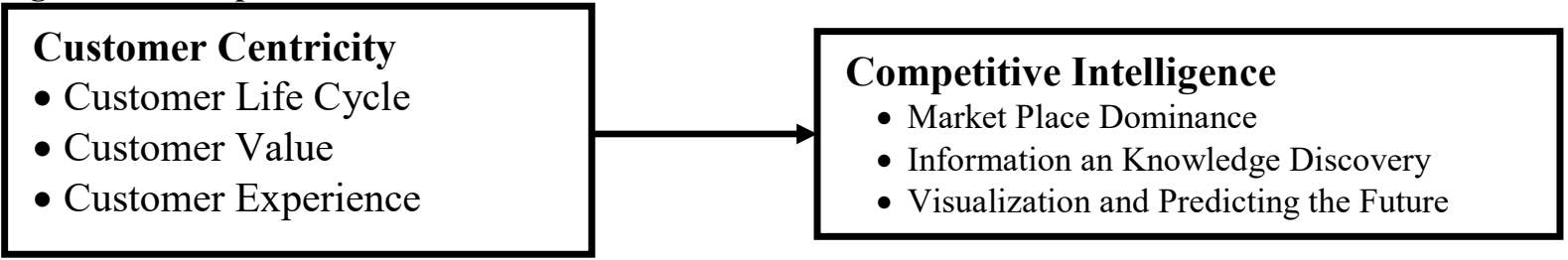

The insurance industry in Kenya has a governing structure that regulates the activities and behaviours of the industry players. This is critical since the industry has been facing the challenge of claim processing and payments. Without regulations clients would be faced with difficulties in lodging their claims, and receiving payments. The relationship between insurance industry and other governance structure as well as consumers is presented in Figure 2.

Figure 2: Structure of Insurance Firms in Kenya

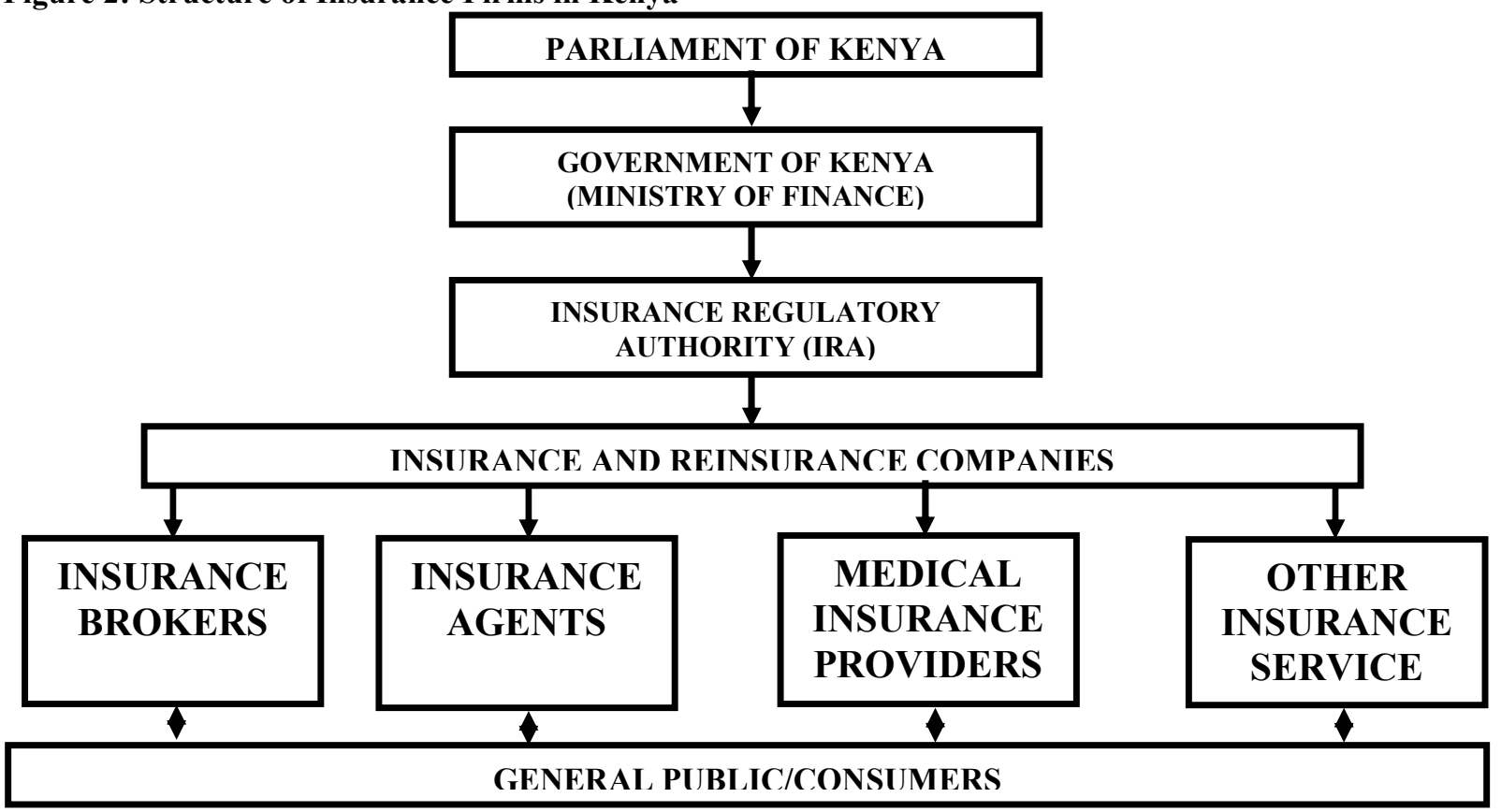

Source: Adapted from Mitullah W. 2015: The Role of the Insurance Regulatory Authority in the Development of the Insurance Industry in Kenya

Customer value centricity as strategy has been widely discussed in the strategy field, where the majority of studies have examined the performance consequences of customer value. Customer value centricity practices mainly deal with functions within an organization (Prescott, 2001). From this it can be deduced that issues relating to new product development, launching a new product on the market, and using facilitative technology such as the Internet, need to be placed within a strategic marketing framework that encompasses the concept of relationship marketing. The relevance of a competitive intelligence industry specific approach has been highlighted by Marceau and Sawka (2001).

Customer life cycle is industry-targeted centricity that is developed on real-time (dynamic) aspects of competitive events taking place among the 4Ps of the marketing mix (pricing, place, promotion, and product) in the product or service marketplace in order to better understand the attractiveness of the market (Fleisher Craig 2003). More recent research has found that conglomerate firms have significantly lower profitability. It has also been shown that highly diversified firms have less market power in their respective markets than more focused firms.

Customer experience centricity exerts a significant influence on the ability to innovate and is viewed both as a major source of competitive advantage and of new product innovation. It is important to link customer experience centricity to competitive intelligence in sustaining competitiveness. Organisations that can combine customer value innovation with customer experience centricity have an increased chance of enjoying sustainable competitive intelligence.

Therefore the need for a better conceptual frame that embraces the external environment in order to understand the nature of completion in the insurance industry. There seems to be a big knowledge gap here pointing out a need for another study in Kenya. 


\subsubsection{Materials and Methodology 8}

Since there is limited study on the Customer Centricity practices and their effect on competitive intelligence, the study sought to investigate the Customer Centricity practices and their effect on competitive intelligence in the insurance sector in Kenya. In this regard, this research problem was studied using mixed method design with an aim to uncover the Customer Centricity practices and their effect on competitive intelligence in the insurance sector in Kenya. A total of 600 potential participants that included top level managers, mid-level and operational level employees of insurance firms operating in Eldoret town of Uasin Gishu county of Kenya were targeted in this study. From this a sample size of 250 was selected to collect primary data. The stratified sampling procedure was used to select the sample size. This allowed the proportional mix of the categories of target population be considered in the sample.

To collect the data, document analysis and questionnaire were used. The experts were asked to evaluate the validity of questionnaires. To do this, the questionnaire was given to some university professors and experts in management. Then, they confirmed the applied modifications and the questionnaires were given to the participants. To determine the questionnaires' reliability, the 'Cronbach Alpha technique' was applied. For this purpose, 40 respondents were chosen randomly and the questionnaires were distributed to them. The study carried out a pilot study to pretest the validity and reliability of data collected using the questionnaire through Cranach's Alpha which measures the internal consistency.

The findings of the pilot study illustrates that all the scales were reliable (Cronbach alpha $=0.926)$ as their reliability values exceeded the prescribed threshold of 0.906 (Hair et al, 2010). The 'Cronbach's Alpha' value for Customer Centricity and competitive intelligence questionnaires were calculated 0.843 and 0.830 respectively. The value supports the reliability of questionnaires, because the calculated results for Cronbach's alpha are more than 0.7 .

Data collected was analyzed using mean, standard deviation including frequency distribution tables, graphs and charts. To analyze the data, SPSS 22.0 and regression and correlation tests were applied. Data was analyzed using descriptive statistics and the discussion was presented. The regression equation $\left(\gamma=\beta_{0}+\beta_{1} X_{1}+\beta_{2} X_{2}+\right.$ $\left.\beta_{3} X_{3}+\varepsilon\right)$ : Whereby $\gamma=$ competitive intelligence, $X_{1}=$ customer life cycle, $X_{2}=$ customer value, $X_{3}=$ customer experience, $\beta_{1}, \beta_{2}, \beta_{3}$, $=$ Coefficients of determination and $\varepsilon=$ error term.

\subsubsection{Ethical Considerations 9}

Before engaging in the study it was considered critical to seek permission to carry out the study. The study respected the individuals' rights and also safeguarded their personal integrity. In the course of this study, the respondents were assured of anonymity, confidentiality and they were also assured of their ability to withdraw from the study at any time if they wish to do so. There were no names or person identification numbers to reflect on the questionnaires except the numbering and identification of data during data editing. The results of the study were availed to the government of Kenya, Treasury and Ministry of Finance, policy makers and the participants who may be interested in knowing the results of the findings.

\subsubsection{Results and Discussion 10}

The study identified various items of Customer Centricity that were measured against the Competitive Intelligence. The items were measured on a Likert scale of 1-5 which ranges from strongly disagree (1) to strongly agree (5). To measure the effects of Customer Centricity a multifactor components to competitive intelligence, Focused Value Added, Employee Engagement, and Employee Commitment questionnaire measured on a Likert scale of 5-points developed by Jun et. al., (2006) was used. This research used multifactor questionnaire on analysis of Competitive Intelligence outcomes regression analysis.

The study managed a response rate of $80.0 \%$ was achieved and good enough for data analysis. According to Mugenda \& Mugenda (2003) a response rate of 50\% is adequate for analysis and generalization of results.

Table 1: Response Rate of Respondents

\begin{tabular}{lcc}
\hline & Frequency & Percentage \\
\hline Total expected & 250 & 100.0 \\
Non - Response & 50 & 20.0 \\
Successful Response & $\mathbf{2 0 0}$ & $\mathbf{8 0 . 0}$ \\
\hline
\end{tabular}

The demographic findings were also obtained, these included gender, age, highest level of education, and the duration of respondents working in the industry.

Table 2: Gender of Respondents

\begin{tabular}{llcl}
\hline Gender & Frequency & Percent \\
\hline Valid & Male & 140 & 70.00 \\
& Female & 60 & 30.00 \\
\hline \multicolumn{2}{c}{ Total } & $\mathbf{2 0 0}$ & $\mathbf{1 0 0 . 0}$ \\
\hline
\end{tabular}

The results in Table 2 indicate that male accounted for $140(70.0 \%)$ while female were $60(30.0 \%)$. This 
means that male were the majority participants in this study. Such phenomena in insurance industry, is an indication that male was a dominant factor in the competitive intelligence of selected insurance firms in Kenyan economy. These results concur with the findings of Li, Shue, and Lee (2008).

\section{Table 3: Age of the Respondents}

\begin{tabular}{lll}
\hline Age (years) & Frequency & Percentage \\
\hline $18-29$ years old & 36 & 18.00 \\
$30-39$ years of age & 64 & 32.00 \\
$40-49$ year of age & 80 & 40.00 \\
50 and above years of age & 20 & 10.00 \\
\hline Total & $\mathbf{2 0 0}$ & $\mathbf{1 0 0 . 0}$ \\
\hline
\end{tabular}

It is discernible from Table 3 that majority of the sample respondents $40.0 \%$ were between $40-49$ years, which was followed in by the age group of 30-39 years of age (32.0\%), 18-29 years old (18.0\%), and those in the bracket of 50 and above years of age $(10.0 \%)$. The above results indicate that majority of the sampled respondents were in the age brackets of 30-49 years of age. It is a potential age as most of the participants have undergone through various operational experiences useful in determining competitive intelligence needed by insurance firms in this industry to boost their level of intelligent. These findings are supported by the findings of Muiva (2001). In his study, he found out that employee experience has significant positive influence on performance.

Table 4: Education Level of Respondents

\begin{tabular}{llll}
\hline Level of Education & Frequency & Percent \\
\hline Valid & Some High School & 30 & 15.0 \\
& High School & 40 & 20.00 \\
& Some College & 80 & 40.00 \\
College Graduate & 50 & 25.00 \\
\hline Total & $\mathbf{2 0 0}$ & $\mathbf{1 0 0 . 0}$ \\
\hline
\end{tabular}

In relations to level of education, the results in Table 4, show that those with some high school qualification accounted for 30 (15.0\%), High School 40 (20.0\%), Some College 80 (40.0\%), while College Graduate 50 $(25.0 \%)$. It infers that majority of participants in this study had some college education during the time of completing this questionnaire. This is an indication that adequate number of sampled respondents represent a level of education qualification critical of access to learned knowledge and skills useful in driving forward insurance industry desire to competitive intelligence development. This finding concurs with that of Ngugi, Gakure and Mugo (2012).

Table 5: Duration in the Insurance Industry Employment

\begin{tabular}{|c|c|c|}
\hline Duration in the post & Frequency & Percent \\
\hline Valid Recently Appointed & 12 & 06.0 \\
\hline Less than 1 year & 18 & 09.0 \\
\hline $1-4$ years & 30 & 15.0 \\
\hline $5-9$ years & 70 & 35.0 \\
\hline 10-above years & 90 & 45.0 \\
\hline Total & 200 & 100.0 \\
\hline
\end{tabular}

The demographic information in Table 5 indicates that most participants had stayed in the industry for more than 5 and above years that accounted for $90(45.0 \%)$. This duration is long enough to have built competitive intelligence in the insurance industry. It also inferred that there are majority of industry experienced people who are assets to the design and development of competitive intelligence. The findings concur with the findings of Baars, and Kemper (2008).

In terms of competitive intelligence, the results revealed that majority $100(50 \%)$ out of 200 total sampled population were of the opinion that products are reviewed annually, followed by semi-annually $40(20 \%)$. That means the institution reviews its products on annual basis, this could be attributed to the increased and rapid changes in technology and customer demands. This finding was supported by Kharis, (2012). 
Table 6: Competitive Intelligence Performance in Insurance Firms

\begin{tabular}{|c|c|c|c|c|}
\hline Statement & SD & $\mathbf{A}$ & $\mathbf{S A}$ & Total \\
\hline $\begin{array}{l}\text { Has been able to move from pushing products to } \\
\text { winning customers }\end{array}$ & $\mathbf{f}(\%)$ & $108(54) 40(20)$ & $32(16) \quad 20(10)$ & $200(100)$ \\
\hline $\begin{array}{l}\text { We have shifted from pruning costs to stimulating } \\
\text { growth, particularly organic growth }\end{array}$ & $\mathbf{f}(\%)$ & $94(47) 60(30) 26$ & (13) $20(10)$ & $200(100)$ \\
\hline $\begin{array}{l}\text { We always launching new products and services } \\
\text { that market demands } \\
\text { My firm increasingly look its customers to drive } \\
\text { growth-tailoring offerings to customers' } \\
\text { unique needs }\end{array}$ & $\mathbf{f}(\%)$ & $78(39) 64(32) 20$ & (10) $38(19)$ & $200(100)$ \\
\hline
\end{tabular}

\section{Strongly Disagree (SD); Disagree (D); Agree (A); Strongly Agree (SA)}

The results in Table 6 indicate that respondents with the strongly disagree and disagree opinions were the majority to all the four statements. There were wider margins of opinions that infer that respondents were fully convinced that the statements given were that the selected firms performed badly. The sampled firms are not able to win customers, instead they are still forcefully pushing products through the throats of customers, there is no organic growth stimulation, new products launch driven by market demand missing, and not able to tailor make growth driven with unique customer needs. This concurs with the findings of Kwach (2018) who found out that insurance investors are simply diving into the insurance business with no idea of what the market really needs. These firms continue to duplicate traditional products and services and so many services missing and offer no solutions to customer needs and customers definitely will not partake of it. According to Tidd (2001) findings, the ability to innovate is increasingly becoming the single most important factor in developing and sustaining competitive advantage.

\subsubsection{Multiple Regression Test 11}

To survey the variables levels Binomial test was applied. It also indicated that all variables were placed in favorable levels. The results of showed that addition, the researcher conducted a multiple regression analysis so as to determine the relationship between customer centricity of insurance firms in Kenya and the four variables. As per the SPSS generated table, the equation $\left(\gamma=\boldsymbol{\beta}_{\mathbf{0}}+\boldsymbol{\beta}_{1} \mathbf{X}_{1}+\boldsymbol{\beta}_{2} \mathbf{X}_{2}+\boldsymbol{\beta}_{3} \mathbf{X}_{\mathbf{3}}+\boldsymbol{\varepsilon}\right)$ becomes: $\boldsymbol{\gamma}=\mathbf{1 . 4 8 6}+\mathbf{- 0 . 2 6 6} \mathbf{X}_{1}$ $+\mathbf{0 . 2 8 6}_{2}+\mathbf{0 . 3 8 9 2}_{3}$ Where $\gamma=$ Competitive Intelligence, $X_{1}=$ customer life cycle, $X_{2}=$ customer value centricity, $\mathrm{X}_{3}=$ customer experience centricity.

According to the regression equation established, taking all factors (customer life cycle, customer value centricity, customer experience centricity constant at zero, the competitive intelligence as a result of customer centricity practices will be 1.486 . Further, taking all other independent variables at zero, a unit increase in customer life cycle practice will lead to a 0.266 increase in $\mathrm{p}$ Competitive Intelligence.

The study identified various items of customer centricity that were measured against the competitive intelligence. The items were measured on a Likert scale of 1-5 which ranges from strongly disagree (1) to strongly agree (5). To measure the effects of customer centricity a multifactor components to competitive intelligence, Customer Life Cycle, Customer Value, and Customer Experience questionnaire measured on a Likert scale of 5-points developed by Jun et. al., (2006) was used. This research used multifactor questionnaire on analysis of competitive intelligence outcomes regression analysis.

This study used regression analysis to find out the relationships between predictive variable and criterion variable. Regression analysis result as shown in Table 7 indicates that customer centricity has significant connection with competitive intelligence.

Table 7: Effects of Customer centricity on Competitive intelligence

\begin{tabular}{|c|c|c|c|c|c|c|}
\hline \multirow[b]{2}{*}{ Model } & \multicolumn{2}{|c|}{$\begin{array}{l}\text { Unstandardized } \\
\text { Coefficients }\end{array}$} & \multicolumn{2}{|c|}{$\begin{array}{l}\text { Standardized } \\
\text { Coefficients }\end{array}$} & \multirow[b]{2}{*}{ Sig. } & \multirow[b]{2}{*}{$\overline{\mathbf{R}^{2}}$} \\
\hline & B & Std. Error & Beta & t-value & & \\
\hline \multicolumn{7}{|l|}{ Constant } \\
\hline Competitive & 1.533 & .114 & 13.427 & & .000 & \\
\hline Intelligence & -.197 & .062 & -.704 & -3.187 & .021 & .0300 \\
\hline \multirow[t]{2}{*}{ Customer Life Cycle } & 3.247 & .265 & 11.560 & & .000 & \\
\hline & -.172 & .068 & -.198 & -2.669 & .008 & .0390 \\
\hline \multirow[t]{2}{*}{ Customer Value } & 3.069 & .232 & 9.350 & & .000 & \\
\hline & .059 & .067 & .065 & .816 & .416 & .0042 \\
\hline \multirow[t]{2}{*}{ Customer Experience } & 3.201 & .332 & 10.457 & & & .000 \\
\hline & -.499 & .057 & -.168 & -2.987 & .298 & .0282 \\
\hline
\end{tabular}

Regression of customer life cycle on competitive intelligence as shown in Table 7 indicates that customer 
life cycle has negative relationship with competitive intelligence outcomes. This infers that customer life cycle has a positive influence on competitive intelligence.

Regression analysis of customer value, customer experience influence competitive intelligence as shown in Table 8 indicates that customer value and customer experience have positive relationship with competitive intelligence. It means that the high level of profitability, Customer referrals and Customer problem solving, the high level of competitive intelligence recorded.

\subsubsection{Correlation Analysis 12}

The correlations of the independent variables of customer life cycle, customer value, and customer experience and the dependent variables competitive intelligence were tested and their significant relationship recorded. This was important to help understand the relationships that exist between the independent and dependent variables. The results are as shown in Table 8.

\section{Table 8: Correlations of Overall Variables}

\begin{tabular}{|c|c|c|c|c|c|}
\hline & & CI & CLC & $\mathrm{CV}$ & $\mathbf{C E}$ \\
\hline \multirow[t]{4}{*}{$\overline{\mathrm{CI}}$} & Pearson & 1 & $.567 * *$ & $.73 * *$ & $-.74 * *$ \\
\hline & Correlation & & & & \\
\hline & Sig. (2 tailed) & & .000 & .001 & .002 \\
\hline & $\mathrm{N}$ & 200 & 200 & 200 & 200 \\
\hline \multirow[t]{4}{*}{ CLC } & Pearson & $.567 * *$ & 1 & $-0.43^{*}$ & $.49 * *$ \\
\hline & Correlation & & & & \\
\hline & Sig. (2 tailed) & .007 & .016 & .006 & .000 \\
\hline & $\mathrm{N}$ & 200 & 200 & 200 & 200 \\
\hline \multirow[t]{4}{*}{$\mathrm{CV}$} & Pearson & $.73 * *$ & $-0.43 * *$ & 1 & .285 \\
\hline & Correlation & & & & \\
\hline & Sig. (2 tailed) & .000 & .016 & .66 & .78 \\
\hline & $\mathrm{N}$ & 200 & 200 & 200 & 200 \\
\hline \multirow[t]{4}{*}{$\mathbf{C E}$} & Pearson & $-.74 * *$ & $.49 * *$ & .285 & 1 \\
\hline & Correlation & & & & \\
\hline & Sig. (2 tailed) & .003 & .004 & .58 & .021 \\
\hline & $\mathrm{N}$ & 200 & 200 & 200 & 200 \\
\hline
\end{tabular}

\section{**Correlation is significant at the 0.01 level $(2$ tailed)}

*Correlation is significant at the 0.05 level (2 tailed)

The results in Table 8 summarize the correlation between the independent variables and dependent variable. It displays that customer life cycle, customer value; and customer experience are all significantly related to competitive intelligence (CI). This relationship is either positive or negative. However, customer experience dimension has significantly negative relationship. This implied that customer life cycle (CLC) is positively associated with competitive intelligence with summary of Pearson Correlations show that Customer Life Cycle was positively and significantly correlated to competitive intelligence with $(r=0.567, \rho<0.05)$.

It infers that customer life cycle had $56.7 \%$ positive relationship with competitive intelligence. Customer Value was also positively related with competitive intelligence $(r=0.73, \rho<0.05)$ an indication that Customer Value had 73.0\% significant positive relationship with competitive intelligence. While Customer Experience was significantly associated with competitive intelligence as shown by $(r=-.74, \rho<0.05)$ implying that customer experience had $74.0 \%$ negative relationship with competitive intelligence.

\subsubsection{Multiple Liner Regression Analysis 13}

The result of regression analysis for both linear and multiple regression analysis provides the functions of the equation that represents the best prediction of a dependent variable from several independent variables. This method is used when the independent variables are correlated with one another and with the dependent variable. The following regression equation is estimated as follow:

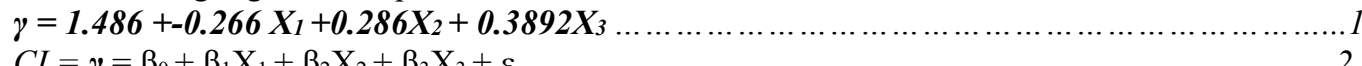

Where: CI: Competitive intelligence

$\alpha 0$ : Constant

CLC: Customer Life Cycle

CV: Customer Value

CE: Customer Experience

$\varepsilon$ : Error term. 
Table 9: Summery of the Regression Model

\begin{tabular}{llllllll}
\hline Model & $\mathbf{R}$ & $\mathbf{R}^{2}$ & $\begin{array}{l}\text { Adjusted } \\
\mathbf{R}^{2}\end{array}$ & $\begin{array}{l}\text { Std. Error } \\
\text { of the } \\
\text { Estimate }\end{array}$ & & $\begin{array}{l}\mathbf{R}^{2} \\
\text { Change }\end{array}$ &
\end{tabular}

Table 9 shows multiple regressions which are related to $\mathrm{CI}$ as dependent variable. The Table shows the influence of independent variable CLC, CV, and CE on dependent variable CI. Results in Table 9 indicate that the independent variables determine $56.7 \%$ of the CI variance. This means that the remaining percentage represent other variables of influence to competitive intelligence. These results concur with the findings of Marceau, and Sawka, (2001).

\subsubsection{Multiple Regression Analysis 14}

A multiple regression analysis was evaluated to determine if there is any influence that customer centricity variable has on competitive intelligence variable. The results of this test were critical for the running of hypotheses tests on individual Customer centricity dimensions. The results are as shown in Table 10.

Table 10: The Coefficients of Multiple Regression Analysis

\begin{tabular}{|c|c|c|c|c|c|}
\hline \multirow[t]{2}{*}{ Model } & \multicolumn{2}{|c|}{ Unstandardized Coefficient } & \multirow{2}{*}{$\begin{array}{c}\begin{array}{c}\text { Standardized } \\
\text { Coefficients }\end{array} \\
\text { Beta }\end{array}$} & \multirow[b]{2}{*}{$\mathrm{t}$} & \multirow[b]{2}{*}{ Sig. } \\
\hline & $\beta$ & Std. Error & & & \\
\hline (Constant) & 1.533 & .114 & & 13.427 & .000 \\
\hline CLC & 1.975 & .238 & .298 & 4.393 & .000 \\
\hline CV & 1.603 & .762 & .066 & .265 & .798 \\
\hline CE & -1.560 & .997 & .027 & .876 & .451 \\
\hline
\end{tabular}

a. Dependent Variable $O P$

$C I=\alpha 0+\beta_{1} C L C+\beta_{2} C V+\beta_{3} C E+\varepsilon$

$1.533+1.975 C L C+1.603 C V-1.5601 C E+\varepsilon$

Table 10 shows the relationship between independent variables namely CLC, CV, and CE on dependent variable CI. Statically, there is significant relationship between the three dimensions of the customer centricity and Competitive intelligence (CI). There is an increasing effect of customer centricity on competitive ,intelligence; CI will increase although some components have decreasing effects. If the Customer centricity dimensions values increase by 1 unit, then competitive intelligence will have an increasing effect of 3.551 units although there will have been a decrease in competitive intelligence of 1.560 . If Customer centricity dimensions are equal to zero, CI will be 1.533 units of level of competitive intelligence. These findings are in agreement with the findings of McGonagle, and Vella, (2004) who found out that there are varous factors that affect competitive intelligence.

\subsubsection{Hypotheses Testing 15}

The effects of customer centricity on competitive intelligence were. Testing the first hypothesis $\left(\mathrm{HO}_{1}\right)$ that stated there is no association between Customer Life Cycle and Competitive intelligence.

This test hypothesis was done by regressing Customer Life Cycle and Competitive intelligence guided by the equation: $\gamma=\beta_{0}+\beta_{1} C L C$ : Where $\gamma$ denotes Competitive intelligence. The results of the regression are presented in Table 11 . 
Table 11: Effect of Customer Life Cycle of Customer centricity on Competitive intelligence

Model Summaryb

\begin{tabular}{|c|c|c|c|c|c|c|}
\hline Model & $\mathrm{R}^{2}$ & $\begin{array}{l}\text { Adjusted } \\
\mathrm{R}^{2}\end{array}$ & $\begin{array}{l}\text { Std. } \\
\text { Estir }\end{array}$ & $\begin{array}{l}\text { ror of the } \\
\text { te }\end{array}$ & Durbin & \\
\hline 1 & $0.567^{\mathrm{a}} \cdot 322$ & .324 & .298 & & .098 & \\
\hline $\begin{array}{l}\text { A. Predictors: } \\
\text { i. Dependent }\end{array}$ & $\begin{array}{l}\text { onstant), } \mathrm{CCCu} \\
\text { riable: } C I\end{array}$ & omer Life Cy & & & & \\
\hline & & & oeffic & $n$ ts $^{a}$ & & \\
\hline Model & $\begin{array}{l}\text { Unst } \\
\text { Coef }\end{array}$ & $\begin{array}{l}\text { ndardized } \\
\text { cients }\end{array}$ & & Standardized & & \\
\hline & $\beta$ & St & rror & Beta & & \\
\hline 1 (Constant) & 1.533 & .11 & & & 13.427 & .000 \\
\hline $\mathrm{CLC}$ & 1.975 & .99 & & .892 & 4.393 & .000 \\
\hline
\end{tabular}

a. Dependent Variable: $C I$

$\gamma=\beta_{0}+\beta_{1} C L C=1.533+1.975 C L C$

The results presented in Table 11 show that the Customer Life Cycle has a significant negative effects on competitive intelligence at $(\mathrm{R}=0.567)$. This was an indication that Customer Life Cycle explained $56.7 \%\left(\mathrm{R}^{2}\right.$ $=.324$ ) of CI. The other variables in the industry and the firms explained the remaining $43.3 \%$. The analysis from the model had the $\mathrm{F}$ value of 19.294. At p-value less than 0.05 , the findings thus were sufficient to support effects of Customer Life Cycle on Competitive intelligence activity level, this infers that Customer Life Cycle had statistically significant positive effects on Competitive intelligence of insurance firms.

The results indicate that there is a significant positive relationship between CLC and Competitive intelligence. When insurance firms make use of customer life cycle such as price, place and promotion then they can understand what stage of customers the products need rebranding for improved services. This would enhance focus on customer at all the period. If the function is $\gamma=\beta_{0}+\beta_{1} C L C=1.533+1.975$ CLC; if CLC is zero $\gamma$ will be 1.533 units level of Competitive intelligence while if CLC is 5 ; $\gamma$ will be $1.533+(1.975 * 5)$ which is equal to 11.408 implying that a positive regressing effects of customer life cycle on competitive intelligence.

The first hypothesis is therefore rejected since the results indicated otherwise. This finding concurred with the findings of Muiva, (2001) who reported that there is a positive relationship between customer centricity and competitive intelligence.

\subsubsection{Second Hypothesis $\left(\mathrm{HO}_{2}\right) \mathbf{1 6}$}

The next objective of this study was to establish the effects of Customer Value on Competitive intelligence. This was evaluated against the indicators of Competitive intelligence. Regression analysis was done to find out if there is any significant effects that the hypothesis could be either or not rejected. This hypothesis was tested by regressing Customer Value and Competitive intelligence using the equation $\gamma=\beta_{0}+\beta_{1} \mathrm{CV} ; \gamma$ denoted Competitive intelligence Activity Level. The results of the regression are presented in Table 12.

Table 12: Relationship between Customer Value and Competitive intelligence

\begin{tabular}{|c|c|c|c|c|c|c|c|}
\hline Model & $\mathbf{R}$ & $\mathbf{R}^{2}$ & $\begin{array}{l}\text { Adj } \\
\mathbf{R}^{2}\end{array}$ & & $\begin{array}{l}\text { Std. E } \\
\text { Estima }\end{array}$ & $\begin{array}{l}\text { rror of } t \\
\text { te }\end{array}$ & \\
\hline 1 & .762 & .066 & .265 & & .798 & & \\
\hline Predictors: (Consta & ustomer & Value & & ff: & & & \\
\hline Model & Un-st & indar & zed & $\begin{aligned} \text { DeIIl } \\
\text { Sta }\end{aligned}$ & ardized & & icance \\
\hline & Coefi & cients & & $\mathrm{Cos}$ & icients & t-value & p-value \\
\hline & $\beta$ & Std $\mathrm{E}$ & & Bet & & & \\
\hline (Constant) & 1.533 & .119 & & & & 3.031 & .052 \\
\hline Customer Value & 1.603 & .762 & & .71 & & 4.544 & .000 \\
\hline
\end{tabular}

. Dependent Variable: Competitive intelligence

- Predictors: (Constant), Customer Value

$\gamma=\beta_{0}+\beta_{1} C V=1.533+1.603 C V$

The results from Table 12 are observation that there is a significant positive relationship between Customer Value and Competitive intelligence $(\mathrm{R}=.854)$. This was an indication that Customer Value explained $73.0 \%$ $\left(\mathrm{R}^{2}=.73\right)$ of Competitive intelligence activity level. The other variables affecting Competitive intelligence activity level explained the remaining $27.0 \%$. The analysis from the model had the F value of 4.5643 at p-value $<0.05$, the findings were sufficient to support the relationship between Customer Value and Competitive intelligence performance, inferring that Customer Value had statistically significant positive effects on Competitive intelligence activity level. 
The strength of customer value such as new product development, launching a new product on the market, and using facilitative technology such as the Internet, need to be placed within a strategic marketing framework that encompasses the concept of relationship marketing are critical in influencing intelligence. Therefore dealing with customer value creation such as excellent alignment of customer and customized customer needs services and satisfaction, launching and relaunching new products, and reviewing of existing customer, use of exhibitions, provision of suit target, differentiation and branding for customer satisfaction are critical to strengthen competitive intelligence. These findings disagree with the findings of Mutua, (2010) and Ngugi, Gakure and Mugo, (2012) and Gainor, R (2014) who found that firms that focus on drivers of competitive intelligence have the ability to perform higher than their competitors.

\subsubsection{Third Hypothesis $\left(\mathrm{HO}_{3}\right) \mathbf{1 6}$}

The third objective of this study was to establish the effects of Customer Experience on Competitive intelligence activity level. This effect of Customer Experience was evaluated based on Beginning Environment, organizational environment, managerial environment and individual environment, while Competitive intelligence was evaluated by considering profitability, learning, growth and processes, and Customer referrals. This generated the third hypothesis $\left(\mathrm{HO}_{3}\right)$ which stated that there is no association between Customer Experience and Competitive intelligence activity level. Hypothesis three sought to establish the influence of Customer Experience on firm competitive intelligence. This hypothesis was tested by regressing Customer Experience and Competitive intelligence activity level guided by the equation $\gamma=\beta_{0}+\beta_{1} E C$ where EC represented Customer Experience and $\gamma$ denoted CI. The results of the regression are presented in Table 13.

Table 13: Effect of Customer Experience on OP

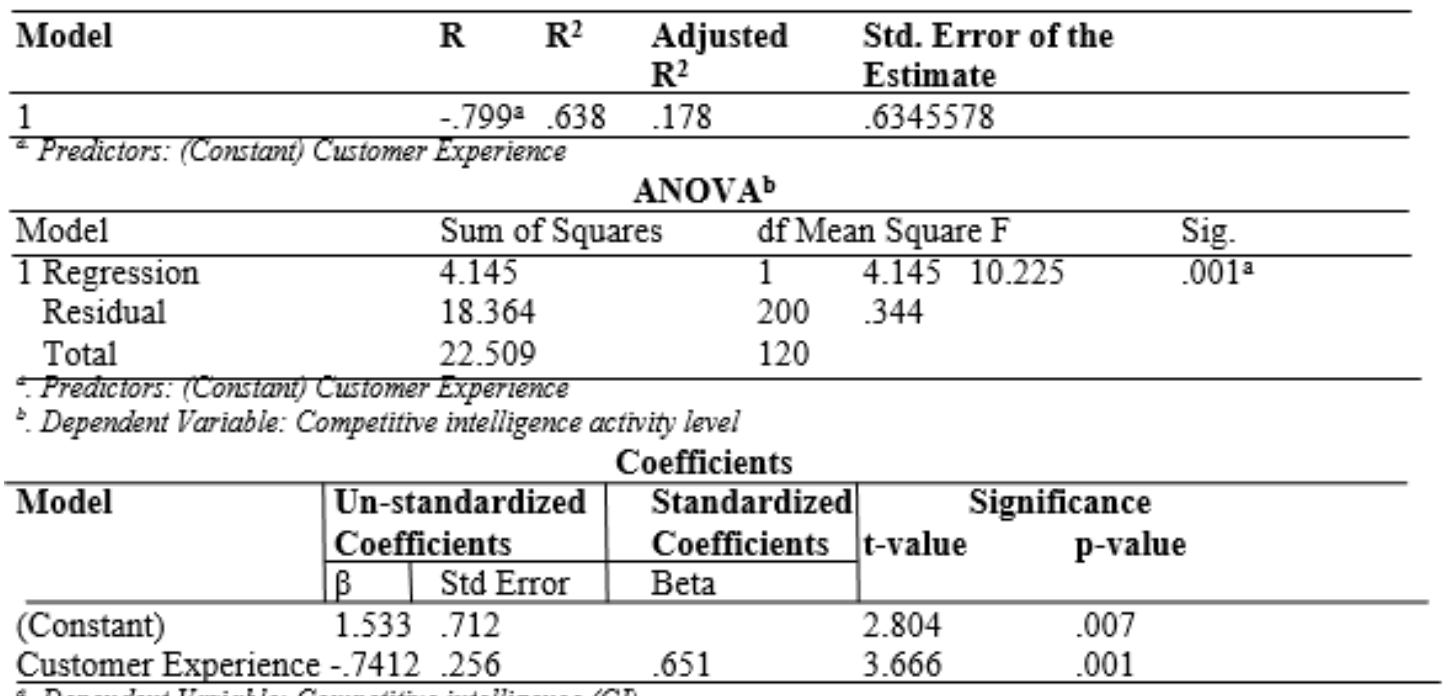

. Dependent Variable: Competitive intelligence (CI)

$\gamma=\beta_{0}+\beta_{1} E C=1.533+(-.7412 C E)$

The results of analysis to establish the effects of Customer Experience dimensions on Competitive intelligence activity level are shown in Table 13. Results indicate a significant negative relationship between Customer Experience and $\mathrm{CI}(\mathrm{R}=-.888)$. The results indicate that a relationship exists between Customer Experience and CI. Customer Experience as a variable explained $74.12 \%(\mathrm{R}=-.7412)$ of Competitive intelligence activity level the remaining $21.1 \%$ explained by other variables. The corresponding $\mathrm{F}$ value for the model was 10.470 at $\mathrm{p}$-value greater than $0.05(\mathrm{p}<0.5)$, hence implying that Customer Experience variable was statistically significant effects on Competitive intelligence level of the firms. Given the equation $\gamma=\beta_{0}+\beta_{1} E C=$ 1.533-.7412EC; when EC is zero $\gamma$ will be .7918 units, while when EC is increased to 10 units, then $\gamma$ will be 8.945 units of Competitive intelligence. This shows increasing effects of CE such as technological innovation, integrating new technology, engaging in custodial services, intelligent monitoring systems, customer driven creativeness and innovation would influence competitive intelligence. Hence the hypothesis that there is no relationship between Customer Experience and Competitive intelligence is rejected.

These findings are in agreement with the findings of Patton, McKenna, (2005) and Prescott, (2001), who found out that there is a significantly negative relationship between customer centricity dimensions and Competitive intelligence. They argued that customer centricity usefulness can be used by increasing winning the customer instead of pushing products through their throats killing their demand desires.

\subsubsection{Conclusions 17}

This study investigated effects of customer centricity on competitive intelligence of insurance firms in Kenya. It was found that there are statistically significant positive and negative relationships between dimensions of 
customer centricity and competitive intelligence. Both customer life cycle and customer value have significant positive relationships while customer experience has significant negative relationship to competitive intelligence.

On customer life cycle, the study concludes that concentration on pricing and customer experience centricity, promotion, customer life cycle segmentation and foreign customer life cycle entry lead to profitability of insurance firms to the full and customer life cycle segmentation. On customer experience centricity intelligence, the study deduces that customer experience centricity development through focused group discussions (FGDs), aligning customer experience centricity with customer needs (customized customer experience centricity), CRM and customer service, customer satisfaction survey, introduction of new customer experience centricity based on customer needs, re-launching and reviewing of existing customer experience centricity make insurance firms more competitive and profitable.

The study concludes that customer value centricity such as technological innovation, customer experience centricity integration with new technology, customer driven customer experience centricity use affect the competitive intelligence of the insurance firms. According to the regression analysis, adoption of customer value centricity practices in the insurance firms contributes most to the competitive intelligence of insurance firms in Kenya followed by customer experience centricity, customer life cycle respectively.

\subsubsection{Recommendations 18}

From the findings and discussions of the study, customer life cycle has enhanced the development of customer life cycle share, decisions making. The study thus recommends that the insurance firms should adopt customer life cycle to enhance efficiency enabling the insurance firms to deal with their large client base, customer focused intelligence and competitive information which lead to increase of the insurance firms competitive intelligence. The study also recommends that for the insurance firms to realize even more profits, they should involve in customer experience centricity intelligence practices such as aligning customer experience centricity with customer needs (customized customer experience), and customer service, customer satisfaction survey, introduction of new customer experience centricity based on customer needs, re-launching and reviewing of existing customer experience centricity. The study found that customer value centricity leads to high levels of automation, cost reduction and efficiency enabling the bank to almost deal seamlessly with their large client base of over 4 million customers. The study therefore recommends that the insurance firms should make use of customer value centricity among other intelligences to increase their competitiveness in terms of customer experience centricity innovation, customer satisfaction and customer life cycle orientation. These centricities ensure that internal strengths of the insurance firms are utilized for the betterment of the firm which leads to competitive intelligence. The study recommends that insurance firms should be more vigorous in establishing customer value and customer experiences which affect their competitive intelligence.

\section{References}

Adidam, P. T., Banerjee, M., \& Shukla, P. (2012). Competitive intelligence and firm's performance in emerging markets: An exploratory study in India. Journal of Business \& Industrial Marketing, 27 (3), 242 - 254.

Baars, H., Kemper, H.G. (2008), Management support with structured and unstructured data - an integrated business intelligence framework, Information Systems Management, Vol. 25 No.2, pp.132-48.

Blenkhorn, D.L. \& Fleisher, C.S. (2007). Performance assessment in competitive intelligence: An exploration, synthesis, and research agenda. Journal of Competitive Intelligence and Management, 4 (2), 4-22.

Bose, R. (2008). Competitive intelligence process and tools for intelligence analysis. Industrial Management \& Data Systems, 108 (4), 510-528.

Central Bank of Kenya, (2010). Annual Bank Report. Nairobi: Government Printers.

Clark, R. M. (2010). Intelligence Analysis (3rd ed.). Washington DC: CQ Press.

Dahl, E. J. (2010). Missing the wake-up call: Why intelligence failures rarely inspire improved performance. Intelligence and National Security, 25 (6), 778-799.

Fleisher \& Craig S. (2003), Should the Field be Called 'Competitive Intelligence?' Westport, CT: Praeger, 2003.

Gainor, R., \& Bouthillier, F. (2014). Conceptualizing outcome and impact measures for intelligence services. Information Research, 19 (1). Retrieved from http://www.informationr.net/ir/191/paper602.html\#.UydEKPldWSo.

Gainor, R., (2014). Measuring Competitive Intelligence Outcomes. Unpublished PhD Thesis McGill University, Canada

Garcia-Alsina, M., Ortoll, E., \& Cobarsí-Morales, J. (2013). Enabler and inhibitor factors influencing competitive intelligence practices. Aslib Proceedings, 65 (3), 262 - 288.

Hair, J.F., Black, W.C., Babin, B.J., Anderson, R.E., Tatham, R.L. (2010), Multivariate Data Analysis, 7th ed., Prentice-Hall, Upper Saddle River, NJ.

Hannula, M., Pirttimaki, V. (2003), Business intelligence empirical study on the top 50 Finnish companies, American Academy of Business, Vol. 2 No.2, pp.593-9.

Kipkorir, S. S. (2001) Competitive Intelligence Practices by FM Radio Stations Operating in Kenya. An 
Unpublished MBA Project, Nairobi; University of Nairobi. Kenya

Korany, A.E. (2007), A knowledge management application in enterprises, International Journal of Management and Enterprise Development, Vol. 4 No.6, pp.693-702.

Kwach, J., (2018). Challenges facing insurance industry in Kenya in 2018

Leslau, O. (2010). The effect of intelligence on the decision making process. International Journal of Intelligence and Counter Intelligence, 23 (3), 426-448.

Li, S.T., Shue, L.Y., Lee, S. (2008), Business intelligence approach to supporting strategy-making of ISP service management, Expert Systems with Applications, Vol. 35 No.3, pp.739-45.

Marceau, S. and Sawka, K. (2001), Developing a world-class CI program in telecoms, Wiley, New York, NY. pp. 148-67.

Matthews, J. R. (2011). Assessing organizational effectiveness: The role of performance measures. The Library Quarterly, 81 (1), 83-110.

McGonagle, J.J. Jr, Vella, C.M. (2004), Competitive intelligence in action, The Information Management Journal, Vol. 38 No.2, pp.64-8.

McKenzie, J., van Winkelen, C., \& Grewal, S. (2011). Developing organisational decision-making capability: A knowledge manager's guide. Journal of Knowledge Management, 15 (3), 403-421.

Muiva C. (2001) A Survey of the Use of Competitive Intelligence Systems in the Kenyan Pharmaceutical Industry. An Unpublished MBA Project, Nairobi; University of Nairobi. Kenya

Mutua, M. (2010) A Research on Competitive Intelligence Practices by Essar Telcom (YU) (K) Ltd. An Unpublished MBA Project, Nairobi; University of Nairobi. Kenya.

Ngugi J. K., Gakure R.W. and Mugo H., (2012); Competitive Intelligence Practices and their Effect on Profitability of Firms in the Kenyan Banking Industry

Patton, K.M., McKenna, T.M. (2005), Scanning for competitive intelligence, Competitive Intelligence Magazine, Vol. 8 No.2, pp.24-9.

Prescott, J.E. (2001), Introduction, in Prescott, J.E. and Miller, S.H. (Eds), Proven Strategies in Competitive Intelligence: Lessons from the Trenches, Wiley, New York, NY. Vol. 6 No. 2, pp. 4-14.

Sharma, R. S., \& Dijaw, V. (2011). Realising the strategic impact of business intelligence tools. VINE, 41 (2), 113-131.

Yap, C. S., \& Rashid, M. Z. A. (2011). Competitive intelligence practices and firm performance. Libri: International Journal of Libraries \& Information Services, 61 (3), 175-189.

\section{Internet Sources:}

http://www.centralbank.go.ke/downloads/nps/psk (accessed 25 May, 2016) Society of Competitive Intelligence Professionals (SCIP) (2008), Resources: Language of BI, available at: www.scip.org/content.cfm?itemnumber=2226\& navItemNumber=2227 (accessed 15 May, 2016). 